\title{
Comparison of Physicochemical Characteristics of Hot-boned Chicken Breast and Leg Muscles during Storage at $20^{\circ} \mathrm{C}$
}

\author{
Long-Hao Yư ${ }^{1}$, Eui-Soo Lee ${ }^{2}$, Hong-Sheng Chen ${ }^{1}$, Jong-Youn Jeong ${ }^{3}$, \\ Yun-Sang Choi ${ }^{4}$, Dong-Gyun Lim ${ }^{5}$, and Cheon-Jei Kim* \\ Department of Food Science and Biotechnology of Animal Resources, Konkuk University, Seoul 143-701, Korea \\ ${ }^{1}$ College of Food Science, Heilongjiang Bayi Agricultural University, Daqing 163-319, China \\ ${ }^{2}$ Genesis BBQ, Icheon 467-813, Korea \\ ${ }^{3}$ Muscle Biology and Meat Science, University of Wisconsin, Madison, WI 53706, USA \\ ${ }^{4}$ Food and Biological Resources Examination Division, Korean Intellectual Property Office, Daejeon 302-701, Korea \\ ${ }^{5}$ Korea Livestock Products HACCP Accreditation Service, Anyang 430-731, Korea
}

\begin{abstract}
The aim of this study was to compare the physicochemical changes of hot-boned chicken breast and leg muscles. Chicken breast and leg muscles from 56 broilers were excised within a 15 min post-mortem (PM) and stored at $20^{\circ} \mathrm{C}$. Physicochemical traits were determined at $0.5,6,12$, and $24 \mathrm{~h}$ PM. The ultimate $\mathrm{pH}$ of leg muscle was higher than that of breast muscle $(p<0.05)$. The content of glycogen in the breast muscle was relatively higher than that in the leg muscle until $6 \mathrm{~h} \mathrm{PM}$ $(p<0.05)$. R-values showing rigor mortis of breast and leg muscles were completed after or before $6 \mathrm{~h} \mathrm{PM}$. Breast muscle had less cooking loss than leg muscle $(p<0.05)$. Drip loss did not significantly differ between breast and leg muscles with the exception of that at $6 \mathrm{~h} \mathrm{PM}$. The sarcomere length of leg muscle was relatively longer than that of breast muscle $(p<0.05)$. The MFI of leg muscle was significantly lower than that of breast muscle $(p<0.05)$. The shear force of leg muscle was lower than that of breast muscle at 6 and $12 \mathrm{~h} \mathrm{PM}(p<0.05)$; however, that of both muscles did not significantly differ at $24 \mathrm{~h} \mathrm{PM}$.
\end{abstract}

Key words: broiler chicken, hot-boning, sarcomere length, myofibrillar fragmentation index, meat tenderness

\section{Introduction}

The marketing of chicken parts is one of the fastest growing segments of the food industry worldwide. Special interest in this field is partially due to the convenience and nutritional value of cuts such as chicken breasts and thighs (Seabra et al., 2001). The breast muscle of chicken meat contains greater levels of white fibres, whereas the leg muscle of chicken meat contains higher levels of red fibres. Generally, red muscle contains more water and fat and less protein than white muscle and has a higher final pH (Chang and Chou, 2010; VegaWarner et al., 1999). Moreover, white muscle contains more glycolytic enzymes, which can stimulate a rapid reaction, speed up the decline in $\mathrm{pH}$, and accelerate rigor

*Corresponding author: Cheon-Jei Kim, Department of Food Science and Biotechnology of Animal Resources, Konkuk University, Seoul 143-701, Korea. Tel: 82-2-450-3684, Fax: 82-2-444-6695, E-mail: kimcj@konkuk.ac.kr mortis in meat (Farouk and Lovatt, 2000). Geesink et al. (1995) reported that the decrease in $\mathrm{pH}$ is related not only to a variety of myofibrils but also to a decrease in muscle temperature, because $\mathrm{pH}$ decline was faster in the M. triceps brachii than that in M. longissimus dorsi, whereas the slower temperature decline in M. triceps brachii.

Many studies have been conducted to investigate the physicochemical characteristics and meat quality of chicken breast and leg muscles. Chang and Chou (2010) and Yu et al. (2005) reported that the $\mathrm{pH}$ values of breast muscles were lower $(p<0.05)$ than those of leg and thigh muscles. Lesiów and Xiong (2003) compared the influence of muscle fibre types on gelation. They observed that the optimal gelling $\mathrm{pH}$ for breast muscle homogenates $(\mathrm{pH}$ 6.3) was slightly higher than that for thigh muscle homogenates (pH 5.8-6.3). Nowsad et al. (2000) determined the collagen content of broiler breast and thigh mince, which showed that the collagen content of broiler breast $(3.9 \mathrm{mg} /$ g) was lower than in thigh $(9.3 \mathrm{mg} / \mathrm{g})$. Liu and Xiong (1996) reported no significant difference $(p>0.05)$ in TBARS 
content between breast and leg muscle myofibril samples. However, little information is available to the comparison to physicochemical characteristics of hot-boned chicken breast and leg muscles after slaughter in $24 \mathrm{~h}$.

One method used to improve the efficiency of chicken meat processing is the immediate removal of poultry meat from the carcasses after slaughter, which is known as "hot-boning" (Hamm, 1983; Lyon et al., 1985). Changing from conventional cold-boning poultry processing to hot-boning methods has gained much interest because of potential savings in labor, space, and energy requirements (Lyon and Hamm, 1986). The process of hot-boning involves removal of muscle from the bone while it is at, or near, body temperature. However, hot-boning adversely affects the texture and juiciness of fillets and breaded chicken portions (Seabra et al., 2001) and increases muscle toughness, which is due to muscle shortening (Lesiak et al., 1996). An increased emphasis has been placed on the research of these meat characteristics, and various methods have been investigated to overcome the toughness associated with hot-boning (Cason et al., 2002; Hamm, 1983; Lyon and Hamm, 1986).

Post-mortem (PM) temperature was noted to be the most important processing factor affecting rigor mortis development and overall meat quality (Lee et al., 1979). De Fremery and Pool (1960) showed a rapid rate of PM glycolysis and the early onset of rigor mortis in birds exposed to $\mathrm{PM}$ temperatures of 37 to $41^{\circ} \mathrm{C}$ during processing. Temperatures ranging from 10 to $25^{\circ} \mathrm{C}$ have been found to have no effect on poultry meat tenderness (Khan, 1971). Therefore, the current experiment was conducted to compare the physicochemical characteristics and meat quality of hot-boned chicken breast and leg muscles during post mortem storage stored at $20^{\circ} \mathrm{C}$.

\section{Materials and Methods}

\section{Muscle sample preparation}

Fifty-six commercially reared broiler chickens ( $6 \mathrm{wk}$ of age with a live weight of approximately $1.5-2.0 \mathrm{~kg}$ ) from a local poultry processor were transported to the Meat Science Laboratory in Konkuk University and held overnight to minimize the effects of catching and handling. The birds were stunned electrically at $50 \mathrm{~V}$ for $10 \mathrm{~s}$ and killed by bleeding for approximately 2 min from a single unilateral neck cut severing the right carotid artery and jugular vein (Yu et al., 2005). Immediately after bleeding and after the skin was peeled off, the breast and leg muscles from the left and right side of the carcasses were excised within 15 min PM and the samples were randomly cut into 4 portions, respectively. The first portion (breast and leg) was used to determine physicochemical characteristics within 30 min after slaughter. The remaining portions were packed separately in polyethylene bags (FoodSaver ${ }^{\circledR}$; CSE, Korea) and stored at $20^{\circ} \mathrm{C}$ until $24 \mathrm{~h}$ PM. The physicochemical properties of these 3 portions were evaluated at 6,12 , and $24 \mathrm{~h} \mathrm{PM}$, respectively.

\section{pH, R-value, and glycogen content}

The $\mathrm{pH}$ of the muscle samples were determined in triplicate using a modification of the iodoacetate method initially described by Jeacocke (1977). Approximately $2 \mathrm{~g}$ of sample were homogenized in $10 \mathrm{~mL}$ of an iodoacetate solution ( $5 \mathrm{mM}$ sodium iodoacetate, $150 \mathrm{mM}$ potassium chloride; $\mathrm{pH}$ adjusted to 7.0 with potassium hydroxide) using an Ultra Turrax (Model No.T25; Janken and Kunkel, Germany) at 10,000 rpm for $1 \mathrm{~min}$; the $\mathrm{pH}$ of the homogenate was determined using a $\mathrm{pH}$ meter (340; Mettle Toledo GmbH, Switzerland).

The R-value was determined using a modification of a method initially described Koh et al. (1993). $4 \mathrm{~g}$ of sample were homogenized in $6 \%$ perchloric acid $\left(\mathrm{HClO}_{4}\right)$ at $5,000 \mathrm{rpm}$ for $90 \mathrm{~s}$, the solution was centrifuged at 3,000 $g$ for $10 \mathrm{~min}, 10 \mathrm{~mL}$ of the supernatant was collected, the $\mathrm{pH}$ was adjusted to $6.0-6.5$ with $2 \mathrm{M} \mathrm{KOH}$, and the solution was chill-stored for $60 \mathrm{~min}$. Thereafter, the solution was filtrated using a Whatman No. 1 filter paper, and 0.1 $\mathrm{mL}$ of the filtrated solution was mixed with $2.9 \mathrm{~mL}$ of 0.1 $\mathrm{M}$ phosphate buffer ( $\mathrm{pH}$ 6.5). Absorbance at 250 and 260 $\mathrm{nm}$ was determined with a UV spectrophotometer (DU650; Beckman, USA). Then, the R-value of $\mathrm{A}_{250} / \mathrm{A}_{260}$ was calculated.

The muscle glycogen content was measured as described by Dreiling et al. (1987), with minor modifications. Approximately $2 \mathrm{~g}$ of muscle were homogenized (Model No. T25; Janken and Kunkel, Germany) for 1 min in 20 $\mathrm{mL}$ of $9 \%$ perchloric acid and then centrifuged (SCR20BA; Hitachi, Japan) at $15,000 \mathrm{~g}$ for $20 \mathrm{~min}$ at $2^{\circ} \mathrm{C}$. The supernatant was filtered and mixed with an iodine color reagent $(0.26 \mathrm{~g}$ of potassium iodide in $10 \mathrm{~mL}$ distilled water and $100 \mathrm{~mL}$ saturated $\mathrm{CaCl}_{2}$ ), and the absorbance at $460 \mathrm{~nm}$ was measured using a spectrophotometer (DU650; Beckman, USA).

\section{Drip loss and cooking loss}

Drip losses from the samples stored at $20^{\circ} \mathrm{C}$ for $24 \mathrm{~h}$ were determined by calculation of weight loss percentage compared with weight before storage. After drip loss 
determination, the samples were bagged with polyethylene bags (Food Saver ${ }^{\circledR}$, CSE, Korea), immersed in a $75^{\circ} \mathrm{C}$ water bath (Model 10-101, Dae Han Co, Korea) for 30 min and cooled at room temperature for $30 \mathrm{~min}$ as described by Yu et al. (2008). After cooling to room temperature, the bags were opened, and the free juice was drained. The cooked samples were blotted with a paper towel and weighed. Cooking loss was measured by weighing the meat before and after cooking.

\section{Sarcomere length}

Sarcomere length was determined by the method (Voyle, 1971) with Helium-Neon-Laser diffraction (spectra-physics, Model No.212-2, USA). At different time of PM, 1-2 g of muscle samples were carefully cut with a knife and immerged in $2 \%$ glutaraldehyde solution with $2 \%$ glucose in a $0.1 \mathrm{M}$ phosphate buffer ( $\mathrm{pH}$ 7.0) of similar temperatures as those at which the muscles were incubated, and sarcomere length was measured.

\section{Myofibrillar fragmentation index (MFI)}

Myofibrils were obtained according to the method of Olson et al. (1976). $4 \mathrm{~g}$ of sample were put into homogenizer with $40 \mathrm{~mL}$ of $2^{\circ} \mathrm{C}$ MFI buffer $\left(20 \mathrm{mM} \mathrm{K}_{2} \mathrm{HPO}_{4} /\right.$ $\mathrm{KH}_{2} \mathrm{PO}_{4}, \mathrm{pH}$ 7, $100 \mathrm{mM} \mathrm{KCl}, 1 \mathrm{mM}$ EDTA, $1 \mathrm{mM} \mathrm{NaN}_{3}$ ), and homogenized at $10,000 \mathrm{rpm}$ for $30 \mathrm{~s}$, then centrifuged at $1,000 \mathrm{~g}$ for $10 \mathrm{~min}$. The supernatant liquid was removed and added $5 \mathrm{v} / \mathrm{w}$ separation media to suspend the sedimentation matter, and then centrifuged again just like above. After repetitions of above operation, the sedimentation matter was suspended with $5 \mathrm{v} / \mathrm{w}$ MFI buffer. Its connective tissue was filtrated with 18 mesh screens, and then the liquid collected was centrifuged with 3 repetitions of the former procedure. Ultimately, the sedimentation matter was suspended in MFI buffer, and the protein concentration of suspension was determined by the biuret method (Cooper, 1977). The myofibrils were suspended in MFI buffer. An aliquot of myofibril suspension was diluted with the MFI buffer to $0.5 \mathrm{mg} / \mathrm{mL}$ protein concentration and the absorbance of this suspension measured at $540 \mathrm{~nm}$. MFI values were recorded as absorbance units per $0.5 \mathrm{mg} / \mathrm{mL}$ myofibril protein concentration multiplied by 200 .

Myofibrillar Fragmentation Index (MFI)

$=$ O.D. at $540 \mathrm{~nm} \times 200$

\section{Warner-Bratzler shear force}

For determining Warner-Bratzler shear force, samples were cooked individually in plastic bags and immersed in a $75^{\circ} \mathrm{C}$ water bath for $30 \mathrm{~min}$. The cooked meats were cooled and sampled at room temperature using a $12.7 \mathrm{~mm}$ circular bore to determine shear force. Four sample cores from each sample were sheared across the length of the core with a Warner-Bratzler shear attachment on the Texture analyser (TA-XT2i, Stable Micro Systems, England) and installed with blade set under cross head speed $2 \mathrm{~mm} /$ s. Texture Expert for the WINDOWS operation system was used to analyze the data. The shear force value was the mean of the maximum forces required to shear each set of core samples and the units used for shear force were Newtons $(\mathrm{N})$.

\section{Statistical analysis}

The Statistical Analysis System (SAS, 1996) was used to calculate means, standard errors and analysis of variance. One-way variance analysis (ANOVA) was performed to compare the effects of storage times on the parameters of samples analyzed immediately after slaughter, and the means test using Dunnett's tests at a 5\% level of significance. Additionally, the analysis of variance was performed by measuring the effects between breast and gel muscles using the minimum square method, and the means were compared using the Student $t$ test $(p<0.05)$.

\section{Results and Discussion}

\section{pH, R-value, and glycogen content}

During storage at $20^{\circ} \mathrm{C}$, chicken breast and leg muscles exhibited great differences in changes of $\mathrm{pH}, \mathrm{R}$-value and glycogen content (Table 1). $\mathrm{pH}$ values of breast muscle were significantly decreased from 6.32 at $0.5 \mathrm{~h}$ PM to 5.82 after $6 \mathrm{~h} \mathrm{PM}$, whereas there were no significant differences among at 6,12 , and $24 \mathrm{~h}$ PM in general agreement with previous study (Stewart and Fletcher, 1984) where reported decreases in $\mathrm{pH}$ values tended to level off at 5.9 after $4 \mathrm{~h}$ or before. Early studies by De Fremery and Pool (1960) revealed that the rigor mortis of chicken muscle was completed at $6 \mathrm{~h}$ before PM and achieved ultimate $\mathrm{pH}$. In addition, $\mathrm{pH}$ of leg muscle significantly decreased from 6.29 at $0.5 \mathrm{~h}$ PM to 6.18 after $6 \mathrm{~h}$ PM. And $\mathrm{pH}$ values of leg muscle at 6,12 , and $24 \mathrm{~h}$ were significantly greater than those of breast muscle $(p<0.05)$. Normally, a decline in $\mathrm{pH}$ is related to the accumulation of lactic acid in the muscle during PM glycolysis (Lawrie, 1991). The results of the current study indicate that the $\mathrm{pH}$ of breast muscle, which contains a greater proportion of white fibrils, declined more rapidly than that of leg 
Table 1. Changes in $\mathrm{pH}, \mathrm{R}$-values, and glycogen contents $(\mathrm{mg} / \mathrm{g}$ tissue) in hot-boned chicken breast and leg muscles during storage at $20^{\circ} \mathrm{C}$

\begin{tabular}{|c|c|c|c|c|c|}
\hline \multirow{2}{*}{\multicolumn{2}{|c|}{ Traits }} & \multicolumn{4}{|c|}{ Postmortem time (h) } \\
\hline & & 0.5 & 6 & 12 & 24 \\
\hline \multirow{2}{*}{$\mathrm{pH}$} & Breast & $6.32^{\mathrm{a}} \pm 0.06$ & $5.82^{b, y} \pm 0.04$ & $5.71^{\mathrm{b}, \mathrm{y}} \pm 0.03$ & $5.73^{\mathrm{b}, \mathrm{y}} \pm 0.02$ \\
\hline & Leg & $6.29^{\mathrm{a}} \pm 0.03$ & $6.18^{\mathrm{b}, \mathrm{x}} \pm 0.04$ & $6.15^{\mathrm{b}, \mathrm{x}} \pm 0.04$ & $6.15^{\mathrm{b}, \mathrm{x}} \pm 0.04$ \\
\hline \multirow{2}{*}{$\begin{array}{c}\text { Glycogen } \\
(\mathrm{mg} / \mathrm{g})\end{array}$} & Breast & $3.25^{\mathrm{a}, \mathrm{x}} \pm 0.10$ & $1.01^{\mathrm{b}, \mathrm{x}} \pm 0.03$ & $0.74^{\mathrm{c}} \pm 0.03$ & $0.72^{\mathrm{c}} \pm 0.03$ \\
\hline & Leg & $1.28^{\mathrm{a}, \mathrm{y}} \pm 0.04$ & $0.81^{\mathrm{b}, \mathrm{y}} \pm 0.02$ & $0.78^{b} \pm 0.02$ & $0.77^{\mathrm{b}} \pm 0.03$ \\
\hline \multirow{2}{*}{ R-value } & Breast & $0.97^{\mathrm{b}} \pm 0.03$ & $1.26^{\mathrm{a}} \pm 0.02$ & $1.27^{\mathrm{a}} \pm 0.01$ & $1.28^{\mathrm{a}} \pm 0.01$ \\
\hline & Leg & $1.01^{\mathrm{c}} \pm 0.02$ & $1.23^{b} \pm 0.01$ & $1.24^{\mathrm{b}} \pm 0.01$ & $1.29^{\mathrm{a}} \pm 0.01$ \\
\hline
\end{tabular}

Values are means \pm SE.

${ }^{\mathrm{a}-\mathrm{c}}$ Means in the same row with different letters are significantly different $(p<0.05)$.

${ }^{\mathrm{x}, \mathrm{y}}$ Means in the same column with different letters are significantly different $(p<0.05)$.

muscle. This result agrees with a previous study by Farouk and Lovatt (2000), who reported that white muscle fibres have a higher rate of glycolytic change than do red fibres and thus have a faster rate of $\mathrm{pH}$ decline. Lesiak et al. (1996) and Northcutt et al. (1994) reported in poultry meat, $\mathrm{pH}$ of leg muscle was higher than that of breast muscle about 0.2-0.3 unit. Also, Wattanachant et al. (2004) and Choe et al. (2010) stated pH of broiler thigh muscle was higher than that of breast muscle.

The R-value is an indirect measure of ATP depletion in the muscle (Mckee and Sams, 1998). During the development of rigor mortis, ATP in the muscle is depleted and the R-value increases because it represents the ratio of inosine- to adenosine-containing compounds in the muscle (Calkins et al., 1982). In the current experiment, Rvalues of the breast muscle were $0.97,1.01,1.26$, and 1.23 at $0.5,6,12$, and $24 \mathrm{~h} \mathrm{PM}$, respectively. R-values of the leg muscle were $1.27,1.24,1.28$, and 1.29 at $0.5,6$, 12 , and $24 \mathrm{~h}$ PM, respectively. The R-values of the breast and leg muscles were not significantly different $(p>0.05)$. The R-values of the breast and leg muscles were greater than 1.2 after $6 \mathrm{~h} \mathrm{PM}$, which indicated that rigor mortis was complete. Previous research has shown that the Rvalues of breast muscle reach values of 0.95-0.97 within 15-30 min PM and of 1.2-1.3 within 2-4 h PM; ultimate R-values were 1.35 (Papa and Fletcher, 1988; Young and Lyon, 1997).

The glycogen content in breast and leg muscles decreased sharply until $6 \mathrm{~h}$ PM $(p<0.05)$ and decreased slowly thereafter. The glycogen content was relatively greater in breast muscle than in leg muscle until $6 \mathrm{~h}$ PM $(p<0.05)$. This finding was similar to that of a previous study conducted by Mckee and Sams (1998), which showed that the glycogen content of Pectoralis muscle from turkey stored at a temperature of $20^{\circ} \mathrm{C}$ decreased sharply until 30 min PM and then decreased slowly thereafter. Fernandez et al. (1995) observed that fast-twitch glycolytic fibres of the Longissimus lumborum [composed predominantly of fast-twitch (89\%) and white (77.3\%) fibres] had a significantly greater glycogen content than did red (fast- and slow-twitch) fibres, whereas slow-twitch fibres of the Semispinalis capitis [composed mainly of red (61.1\%) and fast-twitch (59.3\%) fibres] had a significantly lower glycogen content than did fast-twitch (red and white) fibres. The current study showed that the glycogen content of breast muscle was greater than that of leg muscle, and breast muscle had a faster rate of $\mathrm{pH}$ decline and a lower ultimate $\mathrm{pH}$ than did leg muscle.

\section{Drip loss and cooking loss}

In the current experiment, water holding capacity was determined on the basis of drip loss and cooking loss. Drip loss in both breast and leg muscles increased as the storage period increased, and significant differences were observed between 6 and 24 h PM $(p<0.05)$ (Table 2). However, no significant difference in drip loss was observed between the breast and leg muscles, except at $0.5 \mathrm{~h}$ PM. Cooking losses in breast muscle were not significantly different between the time periods evaluated $(p>0.05)$ (Table 2). In leg muscle, however, significant differences in cooking loss were observed between $0.5 \mathrm{~h}$ and $6 \mathrm{~h}$ PM $(p<0.05)$ but not between 6,12 , and $24 \mathrm{~h} \mathrm{PM}$ $(p>0.05)$. In addition, cooking loss in leg muscle was significantly greater than that in breast muscle during the storage period. These results are in agreement with those reported by Lesiak et al. (1996), who showed that drip loss in both the breast and thigh muscles of turkey meat increased with time at 0,12 , and $30 \mathrm{~h}$ PM temperatures. They also reported that drip loss in thigh muscle was less than that in breast muscle at all temperatures and storage 
Table 2. Changes in cooking loss and drip loss in hot-boned chicken breast and leg muscles during storage at $20^{\circ} \mathrm{C}$

\begin{tabular}{clccrc}
\hline \hline \multirow{2}{*}{ Traits } & & \multicolumn{4}{c}{ Postmortem time (h) } \\
\cline { 2 - 6 } & & 0.5 & 6 & $0.72^{\mathrm{ab}} \pm 0.03$ & 24 \\
\hline Drip loss & Breast & - & $0.65^{\mathrm{b}, \mathrm{x}} \pm 0.03$ & $0.77^{\mathrm{a}} \pm 0.04$ \\
$(\%)$ & Leg & - & $0.54^{\mathrm{b}, \mathrm{y}} \pm 0.02$ & $0.63^{\mathrm{ab}} \pm 0.03$ & $0.72^{\mathrm{a}} \pm 0.04$ \\
\hline Cooking loss & Breast & $15.54^{\mathrm{y}} \pm 0.42$ & $16.67^{\mathrm{y}} \pm 0.39$ & $16.01^{\mathrm{y}} \pm 0.43$ & $16.40^{\mathrm{y}} \pm 0.56$ \\
$(\%)$ & Leg & $26.08^{\mathrm{a}, \mathrm{x}} \pm 0.60$ & $18.45^{\mathrm{b}, \mathrm{x}} \pm 0.35$ & $18.77^{\mathrm{b}, \mathrm{x}} \pm 0.47$ & $19.52^{\mathrm{b}, \mathrm{x}} \pm 0.36$ \\
\hline
\end{tabular}

Values are means $\pm \mathrm{SE}$.

${ }^{a-c}$ Means in the same row with different letters are significantly different $(p<0.05)$.

${ }^{\mathrm{x}, \mathrm{y}}$ Means in the same column with different letters are significantly different $(p<0.05)$.

times evaluated. Northcutt et al. (1994) also reported that leg meat generally has a lower drip loss and a greater water holding capacity than does breast meat, but cooked leg meat had a lower water holding capacity. Treatment and meat type were significant $(p<0.05)$ determinants of drip loss and cooking loss. In addition, Botka-Petrak et al. (2005) reported that white muscle (M. pectoralis superficialis) has a greater water holding capacity than does red muscle (M. iliotibialis lateralis). Wyche and Goodwin (1974) reported that the heat yield of breast meat from broilers was greater than that of leg meat.

\section{Sarcomere lengths, myofibrillar fragmentation index (MFI) and shear force}

Sarcomere length in breast and leg muscles was longest immediately after slaughter $(p<0.05)$, but no significant changes occurred after 6 h PM (Fig. 1). In addition, sarcomere length in leg muscle was longer than that in breast muscle $(p<0.05)$. This result is consistent with that of Beecher et al. (1965), which indicates that red muscles ( $>40 \%$ red fibers) generally have a longer post-rigor sarcomere length than do white muscles $(<30 \%$ red fibers $)$.

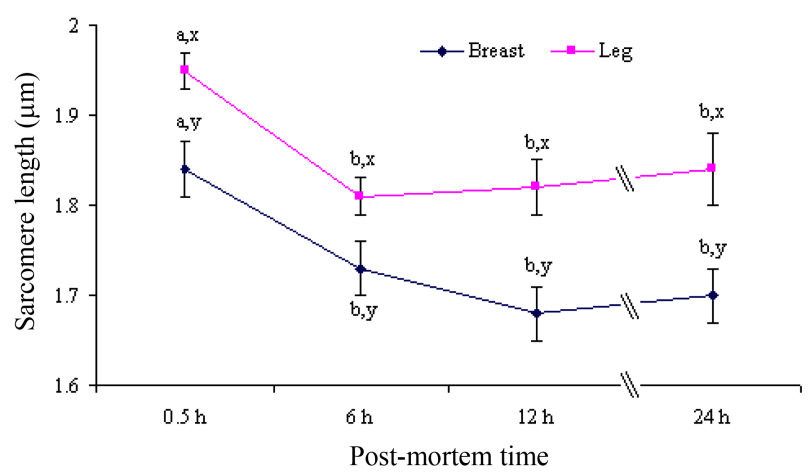

Fig. 1. Changes in sarcomere length $(\mu \mathrm{m})$ in hot-boned chicken breast and leg muscles during storage at $20^{\circ} \mathrm{C}$. ${ }^{a, b}$ Means with different letters are significantly different from each other $(p<0.05)$. ${ }^{\mathrm{x}, \mathrm{y}}$ Means at the same time with different letters are significantly different $(p<0.05)$.
Papa and Fletcher (1988) reported that reduced sarcomere lengths resulted in increased shear force in broiler breast muscle.

In the current study, tenderness was expressed by measuring the myofibrillar fragmentation index (MFI) and shear force values. The MFI of both breast and leg muscles increased during the storage period (Fig. 2). In breast muscle, no significant difference was found between 12 and $24 \mathrm{~h} \mathrm{PM}$; in contrast, a significant difference was found in leg muscle $(p<0.05)$. Kim et al. (1996) reported that the MFI increased slightly until $6 \mathrm{~h}$ PM, regardless of treatment; however, the MFI increased rapidly by $12 \mathrm{~h}$ $\mathrm{PM}$, reaching a value as high as $90 \%$. In addition, the MFI of leg muscle was significantly lower than that of breast muscle during storage at $20^{\circ} \mathrm{C}(p<0.05)$. These phenomena were probably caused by differences in protein components between breast and leg muscles. DaumThunberg, et al. (1992) reported that breast meat had a greater percentage of extractable protein than did thigh meat. Moreover, meat tenderization correlated with the extent of structural protein degradation (Hopkins and Thompson, 2002).

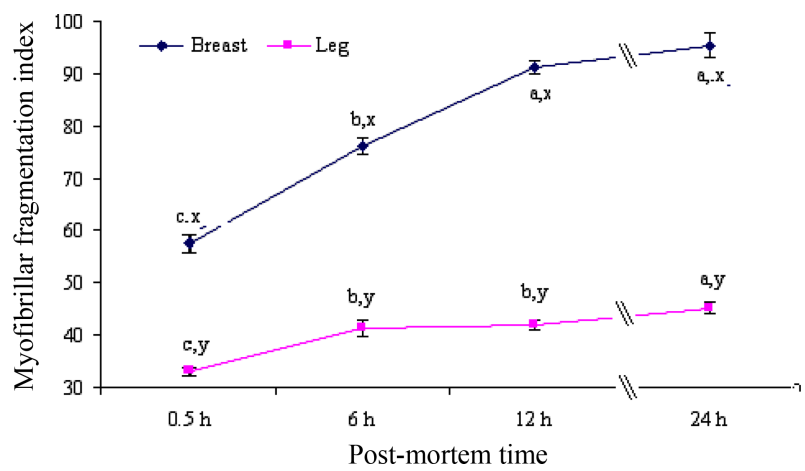

Fig. 2. Changes in the myofibrillar fragmentation index (MFI) in hot-boned chicken breast and leg muscles during storage at $20^{\circ} \mathrm{C}$. ${ }^{\mathrm{a}-\mathrm{c}}$ Means with different letters are significantly different from one another $(p<0.05)$. ${ }^{x, y}$ Means at the same time with different letters are significantly different $(p<0.05)$. 


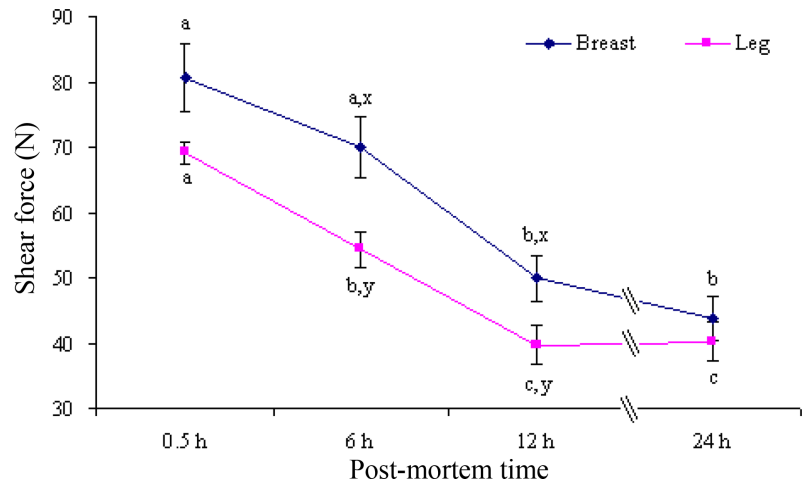

Fig. 3. Changes in Warner-Bratzler shear force $(N)$ in hotboned chicken breast and leg muscles during storage at $20^{\circ} \mathbf{C}$. ${ }^{a-c}$ Means with different letters are significantly different from one another $(p<0.05) .{ }^{\mathrm{x} y}$ Means at the same time with different letters are significantly different $(p<0.05)$.

The shear force of both breast and leg muscles decreased over 24 h PM (Fig. 3). In breast muscles, shear force was not significantly different between $0.5 \mathrm{PM}$ and 6,12 and $24 \mathrm{~h} \mathrm{PM}(p>0.05)$, respectively. In leg muscles, there were significant differences between $0.5,6$, and $12 \mathrm{~h} \mathrm{PM}$, but not between 12 and $24 \mathrm{~h} \mathrm{PM}$. Overall, the shear force of leg muscle was lower than that of breast muscle. This result was slightly different from that of a previous study by Wattanachant et al. (2004), in which no differences in shear values were observed between the M. biceps femoris and the M. pectoralis muscle after they were cooked. However, Liu et al. (1996) observed that the M. biceps femoris muscle was the toughest and the $M$. pectoralis muscle was the most tender chicken muscle. These differences might have been due to different experimental designs.

Generally, a negative correlation has been found between the MFI and shear force (Kandeepan et al., 2009; Olson et al., 1976; Prado and de Felício, 2010; Toohey et al., 2008). However in the current study, the MFI of breast muscle was significantly greater than that of leg muscle during the storage period. Shear force was significantly lower in leg muscle than in breast muscle at 6 and $12 \mathrm{~h}$ PM; however, shear force was not significantly different between leg and breast muscles at $24 \mathrm{~h}$ PM. These different results might due to different experimental material and designs. Kandeepan et al. (2009) and Lametsch et al. (2007) reported that the MFI and shear force showed low correlation. Purchas et al. (2010) indicated the tenderness was correlative with amount of intramuscular fat and sarcomere length.

Consequently, these above results implied the FMI and sarcomere was not suitable to be used as the index of comparing tenderness between chicken breast and leg muscle.

In this study, hot-boning showed important effects on post-mortem physicochemical characteristics of chicken breast and leg muscles during storage at $20^{\circ} \mathrm{C}$. The findings indicate that the glycogen content, water holding capacity, and shear force of breast muscle were higher than those of leg muscle. Early in the PM period, the MFI of breast muscle increased rapidly until $12 \mathrm{~h}$, hereafter, increased only slightly. The MFI of leg muscle increased rapidly until $6 \mathrm{~h} \mathrm{PM}$ and after $12 \mathrm{~h} \mathrm{PM}$; however, it increased only slightly between 6 and $12 \mathrm{~h} \mathrm{PM}$. The ultimate $\mathrm{pH}$ of leg muscle was higher than that of breast muscle, whereas the sarcomere length of leg muscle was longer than that of breast muscle. No significant difference in shear force was found between breast and leg muscles stored at $20^{\circ} \mathrm{C}$ at $24 \mathrm{~h} \mathrm{PM}$. These results demonstrated that hot-boning chicken breast and leg muscle had different post-mortem physicochemical properties.

\section{Acknowledgements}

This study was supported by Technology Development Program (608001-05-1-SB410) for Agriculture and Forestry, Ministry for Agriculture, Forestry and Fisheries, Republic of Korea. The authors also partially supported by the Brain Korean 21 (BK21) Project from Ministry of Education and Human Resources Development.

\section{References}

1. Beecher, G. R., Cassens, R. G., Hoekstra, W. G., and Briskey, E. J. (1965) Red and white fiber content and associated postmortem properties of seven porcine muscles. J. Food Sci. 30, 969-976.

2. Botka-Petrak, K., Vidacek, S., Petrak, T., and Medicì, H. (2005) Influence of combined, continuous chilling on physical and chemical properties of white and red chicken muscles. Veterinarski Arhiv. 75, 415-422.

3. Calkins, C. R., Dutson, T. R., Smith, G. C., and Carpenter, Z. L. (1982) Concentrations of creatine phosphate, adenine nucleotides and their derivatives in electrically stimulated and nonstimulated beef muscle. J. Food Sci. 47, 1350-1353.

4. Cason, J. A. C., Lyon, E. and Dickens, J. A. (2002) Tenderization of hot-boned broiler breast meat by clamping during chilling. Poultry Sci. 81, 121-125.

5. Chang, Y.S. and Chou, R.G. (2010) Postmortem degradation of desmin and calpain in breast and leg and thigh muscles from Taiwan black-feathered country chickens. J. Sci. Food Agric. 90, 2664-2668.

6. Choe, J. H., Nam, K. C., Jung, S. M., Kim, B. N., Yun, H. J., 
and Jo, C. R. (2010) Differences in the quality characteristics between commercial Korean native chickens and broilers. Korean J. Food Sci. Ani. Resour. 30, 13-19.

7. Cooper, T. G. (1977) Biuret protein determination. In "The tools of biochemistry". John Wiley \& Sons, New York. p. 51.

8. Daum-Thunberg, D. L., Foegeding, E. A., and Ball, H. R. Jr. (1992) Rheological and water-holding properties of comminuted turkey breast and thigh: effects of initial pH. J. Food Sci. 57, 333-337.

9. de Fremery, D. and Pool, M. F. (1960) Biochemistry of chicken muscle as related to rigor mortis and tenderization. Food Res. 25, 73-87.

10. Dreiling, C. E., Brown, D. E., Casale, L., and Kelly, L. (1987) Muscle glycogen: comparison of iodine binding and enzyme digestion assays and application to meat samples. Meat Sci. 20, 167-177.

11. Farouk, M. M. and Lovatt, S. J. (2000) Initial chilling rate of pre-rigor beef muscles as an indicator of colour of thawed meat. Meat Sci. 56, 139-144.

12. Fernandez, X., Lefaucheur, L., and Čandek, M. (1995) Comparative study of two classifications of muscle fibres: consequences for the photometric determination of glycogen according to fibre type in red and white muscle of the pig. Meat Sci. 41, 225-235.

13. Geesink, G. H., Koolmees, P. A., van Laack, H. L. J. M., and Smulders, E. J. M. (1995) Determinants of tenderisation in beef longissimus dorsi and triceps brachii muscles. Meat Sci. 41, 7-17.

14. Hamm, D. (1983) Techniques for reducing toughness in hotstripped broiler meat. Poultry Sci. 62, 1430.

15. Hopkins, D. L. and Thompson, J. M. (2002) Factors contributing to proteolysis and disruption of myofibrillar proteins and the impact on tenderisation in beef and sheep meat. Aust. J. Agric. Res. 53, 149-166.

16. Jeacocke, R. E. (1977) Continuous measurements of the $\mathrm{pH}$ of the beef muscle in intact beef carcasses. J. Food Technol. 12, 375-386.

17. Kandeepan, G., Anjaneyulu, A. S. R., Kondaiah, N., Mendiratta, S. K., and Lakshmanan, V. (2009) Effect of age and gender on the processing characteristics of buffalo meat. Meat Sci. 83, 10-14.

18. Khan, A. W. (1971) Effects of temperature during post-mortem glycolysis and dephosphorylation of high energy phosphates on poultry meat tenderness. J. Food Sci. 36, 120-121.

19. Kim, O. H., Park, C. I., and Park, Y. S. (1996) Effect of chitosan additive feeding on the tenderness of broiler meat. Korean J. Food Sci. Ani. Resour. 16, 62-66.

20. Koh, K. C., Binder, T. D., McMillan, K. W., and Kim, M. B. (1993) The relationship between ATP and R-values in postmortem bovine longissimus dorsi muscle. Meat Sci. 33, 253263.

21. Lametsch, R., Knudsen, J. C., Ertbjerg, P., Oksbjerg, N., and Therkildsen, M. (2007) Novel method for the determination of myofibril fragmentation post-mortem. Meat Sci. 75, 719724.

22. Lawrie, R. A. (1991) Meat science. 5th ed, Pergamon Press,
New York.

23. Lee, Y. B., Hargus, G. L., Webb, J. E., Rickansrud, D. A., and Hagberg, E. C. (1979) Effect of electrical stimulation on post-mortem biochemical changes and tenderness in broiler breast muscle. J. Food Sci. 44, 1121-1122.

24. Lesiak, M. T., Olson, D. G., Lesiak, C. A., and Ahn, D. U. (1996) Effects of post-mortem temperature and time on the water-holding capacity of hot-boned turkey breast and thigh muscle. Meat Sci. 43, 51-60.

25. Lesiów, T. and Xiong, Y. L. (2003) Chicken muscle homogenate gelation properties: effect of $\mathrm{pH}$ and muscle fiber type Meat Sci. 64, 399-403.

26. Liu, A., Nishimura, T., and Takahashi, K. (1996) Relationship between structural properties of intramuscular connective tissue and toughness of various chicken skeletal muscles. Meat Sci. 43, 43-49.

27. Liu, G. and Xiong, Y. L. (1996) Contribution of lipid and protein oxidation to rheological differences between chicken white and red muscle myofibrillar proteins. J. Agric. Food Chem. 44, 779-784.

28. Lyon, B. G. and Hamm, D. (1986) Effects of mechanical tenderization with sodium chloride and polyphosphates on sensory attributes and shear values of hot-stripped broiler breast meat. Poultry Sci. 65, 1072-1707.

29. Lyon, C. E., Hamm, D., and Thomson, J. E. (1985) pH and tenderness of broiler breast meat deboned various times after chilling. Poultry Sci. 64, 307-310.

30. McKee, S. R. and Sams, A. R. (1998) Rigor mortis development at elevated temperatures induces pale exudative turkey meat characteristics. Poultry Sci. 77, 169-174.

31. Northcutt, J. K., Foegeding, E. A., and Edens, F. W. (1994) Water-holding properties of thermally preconditioned chicken breast and leg meat. Poultry Sci. 73, 308-316.

32. Nowsad, A. A. K. M., Kanoh, S., Niwa, E. (2000) Thermal gelation characteristics of breast and thigh muscles of spent hen and broiler and their surimi. Meat Sci. 54, 169-175.

33. Olson, D. G., Parrish, F. C. Jr., and Stromer, M. H. (1976) Myofibril fragmentation and shear resistance of three bovine muscles during post-mortem storage. J. Food Sci. 41, 10361041.

34. Papa, C. M. and Fletcher, D. L. (1988) Pectoralis muscle shortening and rigor development at different locations within the broiler breast. Poultry Sci. 67, 635-640.

35. Prado, C. S. and de Felício, P. E. (2010) Effects of chilling rate and spray-chilling on weight loss and tenderness in beef strip loin steaks. Meat Sci. 86, 430-435.

36. Purchas Roger, W., Triumf Ellen, C., and Egelandsdal, B. (2010) Quality characteristics and composition of the longissimus muscle in the short-loin from male and female farmed red deer in New Zealand. Meat Sci. 86, 505-510.

37. SAS (1996) User's Guide: Statistics. Version $6^{\text {th }}$ ed, SAS Institute, Inc., Cary, NC. USA.

38. Seabra, L. M., Zapata, J. F., Fuentes, M. F., Aguiar, C. M., Freitas, E. R., and Rodrigues, M. C. (2001) Effect of deboning time, muscle tensioning, and calcium chloride marination on texture characteristics of chicken breast meat. 
Poultry Sci. 80, 109-112.

39. Stewart, M. K. and Fletcher, D. L. (1984) The influence of hot boning broiler breast muscle and $\mathrm{pH}$ decline and toughening. Poultry Sci. 63, 1935-1939.

40. Toohey E S, Hopkins D L, Stanley D F, and Nielsen S G. (2008) The impact of new generation pre-dressing mediumvoltage electrical stimulation on tenderness and colour stability in lamb meat. Meat Sci. 79, 683-691.

41. Vega-Warner, V., Merkel, R. A., and Smith, D. M. (1999) Composition, solubility and gel properties of salt soluble proteins from two bovine muscle types. Meat Sci. 51, 197203.

42. Voyle, C. A. (1971) Sarcomere length and meat quality. Proceed. $17^{\text {th }}$ Eur. Meeting Meat Res. Workers, Bristol, England, pp. 95-97.
43. Wattanachant, S., Benjakul, S., and Ledward, D. A. (2004) Composition, color, and texture of Thai indigenous and broiler chicken muscles. Poultry Sci. 83, 123-128.

44. Wyche, R. C. and Goodwin, T. L. (1974) Hot-cutting of broilers and its influence on tenderness and yield. Poultry Sci. 53, 1668-1675.

45. Young, L. L. and Lyon, C. E. (1997) Effect of calcium marination on biochemical and textural properties of peri-rigor chicken breast meat. Poultry Sci. 76, 197-201.

46. Yu, L. H., Lee, E. S., Jeong, J. Y., Paik, H. D., Choi, J. H., and Kim, C. J. (2005) Effects of thawing temperature on the physicochemical properties of pre-rigor frozen chicken breast and leg muscles. Meat Sci. 71, 375-382.

$\overline{\text { (Received 2011.5.20/Revised 2011.8.31/Accepted 2011.9.19) }}$ 